\title{
Implications of in vitro mutagenesis in Banana (Musa spp.)
}

\author{
Muharram Ali ${ }^{1}$, Ghulam Shah Nizamani ${ }^{2 *}$, Muhammad Tahir Khan ${ }^{2}$, \\ Shafquat Yasmeen ${ }^{2}$, Asma Siddiqui ${ }^{1}$, Imtiaz Ahmed Khan ${ }^{2}$, Muhammad \\ Rashid Nizamani ${ }^{3}$, Faiza Nizamani ${ }^{4}$, Mohammad Aquil Siddiqui ${ }^{2}$ and \\ Mazhar Ali Khaskheli ${ }^{1}$ \\ 1. Department of Biotechnology, Sindh Agriculture University, Tandojam-Pakistan \\ 2. Biotechnology Group, Nuclear Institute of Agriculture (NIA), Tandojam-Pakistan \\ 3. College of Forestry, Northwest A\&F University, Yangling-China \\ 4. Department of Plant Breeding and Genetics, Sindh Agriculture University, Tandojam-Pakistan \\ *Corresponding author's email: nizamanigs@ gmail.com
}

Citation

Muharram Ali, Ghulam Shah Nizamani, Muhammad Tahir Khan, Shafquat Yasmeen, Asma Siddiqui, Imtiaz Ahmed Khan, Muhammad Rashid Nizamani, Faiza Nizamani, Mohammad Aquil Siddiqui and Mazhar Ali Khaskheli. Implications of in vitro mutagenesis in Banana (Musa spp.). Pure and Applied Biology. Vol. 9, Issue 1, pp12301241. http://dx.doi.org/10.19045/bspab.2020.90003

\begin{tabular}{llll}
\hline \hline Received: 09/05/2019 & Revised: 15/07/2019 & Accepted: 08/09/2019 & Online First: 18/09/2019 \\
\hline
\end{tabular}

\section{Abstract}

Banana is an important crop of Pakistan, grown on large scale in Sindh province of the country. This study was conducted to introduce genetic variability in banana variety basrai and to optimize the micropropagation protocol for the same genotype. Murashige and Skoog (MS) media supplemented with various concentrations of indole-3-acetic acid (IAA), N6benzyl aminopurine (BAP), indole-3-butyric-acid (IBA) and naphthalene acetic acid (NAA) were used. The genotypes were also radiated via. three different doses of gamma radiation i.e. 10, 20 and $30 \mathrm{~Gy}$. Excellent shoot growth and elongation parameters viz. number of shoots developed bottle ${ }^{-1}(25.77)$ and shoot length $(17.44 \mathrm{~cm})$ were recorded in plantlets cultured on MS media supplemented with $4.00 \mathrm{mg} \mathrm{l}^{-1} \mathrm{IAA}+6.00 \mathrm{mg} \mathrm{l}^{-1} \mathrm{IBA}+4.00 \mathrm{mg} \mathrm{l}^{-1} \mathrm{NAA}$ and $40 \mathrm{~g} \mathrm{l}^{-1}$ sucrose; and radiated using 20 Gy dose of gamma radiation. The same combination of culture media and gamma rays' treatment also showed least days to shoot initiation. Minimum observations for the growth parameters were observed in plantlets radiated with $30 \mathrm{~Gy}$ of gamma radiation and grown in MS media containing $2.00 \mathrm{mg} \mathrm{l}^{-1} \mathrm{IAA}+2.00 \mathrm{mg} \mathrm{l}^{-1} \mathrm{BAP}+2.00 \mathrm{mg} \mathrm{l}^{-1}$ NAA and $40 \mathrm{~g} \mathrm{l}^{-1}$ sucrose. Regarding treatments of gamma radiation used in the study, lower doses like 10 and 20 Gy showed stimulatory effects on plantlets' growth and development while 30 Gy was lethal. This study is significant for banana breeding as apposite induction of genetic variation through mutagenesis and optimal maintenance in the tissue culture will help in developing elite genotypes having near-commercial attributes.

Keywords: Banana; Gamma Radiation; Micropropagation; Musa spp.; Tissue culture

Introduction

Banana is a large perennial herb (Musa spp.). It comes from the monocotyledonous family Musaceae. It is a major fruit crop cultivated in more than 120 countries throughout the tropics and subtropics, where 
it makes a significant contribution towards food security and income generation [1-4]. Because of the popularity of banana fruits for its nutritional characteristics, the demand for banana production is escalating continuously in several countries including Pakistan [5].

Banana is grown on an area of 29.20 thousand ha in Pakistan and the total production of the country is 134.90 thousand tonnes. The average yield of banana in the country is only $4600 \mathrm{~kg} \mathrm{ha}^{-1}$ which is far less than other banana producing nations [6-8]. In the same region, India, the largest banana producer, has an average yield of around $35,500 \mathrm{~kg} \mathrm{ha}^{-1}$. The huge differences in yield denote unexplored potential for augmenting the productivity of banana in Pakistan [8]. Hence, there is a strong need of developing local banana varieties as well as working on production technology for harvesting the apposite yields of this staple crop in the country.

Since banana is propagated vegetatively in Pakistan, the genetic variability cannot be obtained through hybridization-based approaches. Routes of mutagenesis and the use of tissue culture can therefore play important role as the alternate options in banana breeding [9]. Tissue culture hence plays an important part in developing new banana varieties. Even for selection of irradiated material, the plant material needs to undergo tissue culture operations [10]. Thus, it is of paramount importance to optimize the tissue culture procedures for radiated material.

Plant growth regulators play a vital role to determine the developmental pathways of the plant cells. Success of in vitro propagation of banana is dependent on the induction and differentiation of plantlets, which is possible only in presence of appropriate hormones in suitable concentrations in the media [11]. The technique of plant tissue culture has emerged as an excellent tool of plant biotechnology [12-15]. In plant tissue culture, cytokinins enhance buds growth as well as shoot formation, while auxins boost rooting $[16,17]$. Benzylaminopurine (BAP) in combination with auxins (IAA and NAA), produce synergistic outcomes [5, 18-20]. Tissue culture approaches also provide elevated rates of multiplying genetically homogeneous, pest and disease-free planting material [21, 22].

Induced mutation techniques are especially important for crops like banana as they lack sexual reproduction which could otherwise provide the genetic variability for selection. Mutagenic treatments on in vivo sucker material has been proved to be less effective and yield low mutagenized material for further screening [23]. In case of in vitro approaches, lower doses of gamma radiation have even been observed to play stimulatory role for explants' growth and shoot formation, as well as leaf expansion; however, higher doses play an inhibitory part [24].

This study was conducted to create genetic variability in a top banana variety widely cultivated in Pakistan i.e. Basrai. Three different doses of gamma radiation including 10, 20 and 30 Gy were applied on the plantlets. Moreover, various compositions of growth regulators were employed in order to investigate the growth response of the radiated material against hormonal concentrations used. The study carries substantial significance for banana breeding and tissue culture as optimal doses of gamma radiation as well as concentrations of plant growth regulators for shoot development in banana are reported.

\section{Materials and methods}

The experiment was conducted at Tissue Culture Laboratory of Nuclear Institute of Agriculture, (NIA) Tando Jam. Randomized complete block design (RCBD) was used with three replications in the study. Suckers 
of the banana variety basrai were collected from healthy plants from Experimental Farm of the institute. After removing extra tissues, suckers were dipped in $70 \%$ ethanol for one minute followed by $10 \%$ in sodium hypochlorite $(\mathrm{NaClO})$ solution for twenty minutes. Then, the suckers were thoroughly washed with sterile distilled water to remove the residue of sodium hypochlorite. These aseptically isolated shoot tips of explants (3$4 \mathrm{~mm}$ in size) were cultured as the starting material.

The explants were cultured on MS full strength basal media having different strengths of growth regulators for shoot induction. Various concentrations of growth hormones were added in the culture media to investigate impact on banana micropropagation. MS media supplemented with four different concentrations of three growth regulators viz. indole-3-acetic acid (IAA), N6-benzylaminopurine (BAP), and naphthalene acetic acid (NAA) were experimented. Sucrose concentration was maintained at $4 \%$. IAA was supplied in concentrations of 2.00,3.00, 4.00, $5.00 \mathrm{mg} \mathrm{l}^{-}$ 1 ; BAP in concentration of 2.00 , and 4.00 $\mathrm{mg} \mathrm{1}^{-1}$; IBA in concentration of 6.00 and $8.00 \mathrm{mg} \mathrm{l}^{-1}$; and NAA was supplemented in concentration of 2.00,3.00, 4.00, and 5.00 $\mathrm{mg} \mathrm{l}^{-1}$. Thus, following four different media compositions were finally used for shoot induction.

- $\quad \mathrm{MS}+2.00 \mathrm{mg} \mathrm{l}^{-1} \mathrm{IAA}+2.00 \mathrm{mg} \mathrm{l}^{-1}$ $\mathrm{BAP}+2.00 \mathrm{mg} \mathrm{l}^{-1} \mathrm{NAA}+40 \mathrm{~g} \mathrm{l}^{-1}$ sucrose

- $\quad \mathrm{MS}+3.00 \mathrm{mg} \mathrm{l}^{-1} \mathrm{IAA}+4.00 \mathrm{mg} \mathrm{l}^{-1}$ $\mathrm{BAP}+3.00 \mathrm{mg} \mathrm{l}^{-1} \mathrm{NAA}+40 \mathrm{~g} \mathrm{l}^{-1}$ sucrose - $\quad \mathrm{MS}+4.00 \mathrm{mg} \mathrm{l}^{-1} \mathrm{IAA}+6.00 \mathrm{mg} \mathrm{l}^{-1}$ $\mathrm{IBA}+4.00 \mathrm{mg} \mathrm{l}^{-1} \mathrm{NAA}+40 \mathrm{~g} \mathrm{l}^{-1}$ sucrose - $\quad \mathrm{MS}+5.00 \mathrm{mg} \mathrm{l}^{-1} \mathrm{IAA}+8.00 \mathrm{mg} \mathrm{l}^{-1}$ $\mathrm{IBA}+5.00 \mathrm{mg} \mathrm{l}^{-1} \mathrm{NAA}+40 \mathrm{~g} \mathrm{l}^{-1}$ sucrose Culture media was solidified using $4.0 \mathrm{~g}$ gelrite per litre. The $\mathrm{pH}$ was attuned to 5.7 to 5.8 .

After establishing the banana plantlets, they were radiated with three doses of gamma radiation for producing genetic variability. 10, 20 and 30 Gy of radiation were applied through gamma source ${ }^{60} \mathrm{Co}$ (ModelTheratron-780) @ 1.40 Gy per minute using the facility provided by Nuclear Institute of Medical and Radiotherapy (NIMRA), Jamshoro. An unirradiated bottle of each concentration was used as control. During growth period after the radiation treatment, temperature of the culture material was kept around $25 \pm 2{ }^{\circ} \mathrm{C}$. The growth observations were recorded after sub-culturing the plantlets two times. The recorded parameters included days to initiation bottle $\mathrm{e}^{-1}$, number of shoots bottle ${ }^{-1}$, shoot length $(\mathrm{cm})$ and number of leaves ${ }^{-1}$. The experimental data were subjected to analysis of variance (ANOVA), and least significant difference (LSD) test using Student Edition of Statistics (SWX), Version 8.1 [25].

\section{Results and discussion}

\section{Days to shoot initiation bottle ${ }^{-1}$}

The statistical analysis of variance indicated that early days taken to shoots initiation were highly significant for hormonal concentrations and doses of gamma radiation, as well as their combinatorial impact at $5 \%$ probability level (data are presented in table 1; statistical analysis has been presented in table 2). The mean results of different plant growth regulator concentrations indicated that early days taken to shoot initiation were recorded (26.08 and 27.88) under the MS media supplemented with $4.00 \mathrm{mg} \mathrm{l}^{-1} \mathrm{IAA}+6.00$ $\mathrm{mg} \mathrm{l}^{-1} \mathrm{IBA}+4.00 \mathrm{mg} \mathrm{l}^{-1} \mathrm{NAA}+40 \mathrm{~g} \mathrm{l}^{-1}$ sucrose and the MS media containing 3.00 $\mathrm{mg} \mathrm{l}^{-1} \mathrm{IAA}+4.00 \mathrm{mg} \mathrm{l}^{-1} \mathrm{BAP}+3.00 \mathrm{mg} \mathrm{l}^{-1}$ $\mathrm{NAA}+40 \mathrm{~g} \mathrm{l}^{-1}$ sucrose, while late days taken to shoot initiation were observed (31.00) under the media concentration of $\mathrm{MS}+2.00 \mathrm{mg} \mathrm{l}^{-1} \mathrm{IAA}+2.00 \mathrm{mg} \mathrm{l}^{-1} \mathrm{BAP}+$ $2.00 \mathrm{mg} \mathrm{l}^{-1} \mathrm{NAA}+40 \mathrm{~g} \mathrm{l}^{-1}$ sucrose.

The mean results of different gamma radiation doses showed that early days taken 
to shoot initiation were obtained at $20 \mathrm{~Gy}$ (24.55 days), followed by 10 Gy (27.88 days) and late days taken to shoot initiation were recorded at $30 \mathrm{~Gy}$ and under control (29.00 and 33.16 days, respectively). The interaction of different plant growth regulator concentrations and gamma radiation doses showed that early days taken to shoot initiation, i.e. 21.55 days, were recorded under the MS media supplemented with $4.00 \mathrm{mg} \mathrm{l}^{-1} \mathrm{IAA}+6.00 \mathrm{mg} \mathrm{l}^{-1} \mathrm{IBA}+$ $4.00 \mathrm{mg} \mathrm{l}^{-1} \mathrm{NAA}+40 \mathrm{~g} \mathrm{l}^{-1}$ sucrose at 20Gy, followed by 24.55 and 24.22 days on media composition of $\mathrm{MS}+4.00 \mathrm{mg} \mathrm{l}^{-1} \mathrm{IAA}+6.00$ $\mathrm{mg} \mathrm{l}^{-1} \mathrm{IBA}+4.00 \mathrm{mg} \mathrm{l}^{-1} \mathrm{NAA}+40 \mathrm{~g} \mathrm{l}^{-1}$ sucrose and $\mathrm{MS}+3.00 \mathrm{mg} \mathrm{l}^{-1} \mathrm{IAA}+4.00$ $\mathrm{mg} \mathrm{l}^{-1} \mathrm{BAP}+3.00 \mathrm{mg} \mathrm{l}^{-1} \mathrm{NAA}+40 \mathrm{~g} \mathrm{l}^{-1}$ sucrose at $10 \mathrm{~Gy}$ and $20 \mathrm{~Gy}$, respectively. On the other hand, late days taken to shoot initiation were seen under the concentration of $\mathrm{MS}+2.00 \mathrm{mg} \mathrm{l}^{-1} \mathrm{IAA}+2.00 \mathrm{mg} \mathrm{l}^{-1} \mathrm{BAP}$ $+2.00 \mathrm{mg} \mathrm{l}^{-1} \mathrm{NAA}+40 \mathrm{~g} \mathrm{l}^{-1}$ sucrose at 30Gy (35.77 days).

Kulkarni et al. observed similar results suggesting that lower doses of gamma radiation, did not produce detrimental effects on development of banana plantlets [26]; however, higher doses proved to be lethal. For the cultivar Gran Nain, they mentioned the dose of $40 \mathrm{~Gy}$ as an injurious one. Similarly, Khatri et al. investigated the in vitro mutation induction by using gamma radiation doses at 20,30, 40 and $60 \mathrm{~Gy}$ and found that the plantlets exposed to higher doses took more days to shoot initiation [27]. In another report, similar to our observations, Mishra et al. [28] radiated three banana cultivars (Basari, Chakkarakela and Rasthali) using gamma radiation doses and found that 10 and $20 \mathrm{~Gy}$ induced good response for plantlets' development, while 30 Gy showed lethal affects. Ferid et al. [29] also used gamma radiation-based treatments, ranging from 10 to $70 \mathrm{~Gy}$, to induce genetic variability in banana cv. Tanduk and suggested that 10 and 20 Gy were superior among the doses used. Likewise, in this study, the doses of 10 and 20 Gy produced positive changes regarding plantlets' development through shoot-tip tissue culture; nevertheless, the 30 Gy dose did harm the development of shoots. Hence, it was evident that for creating genetic variability in banana, lower doses of gamma radiation should be applied. Furthermore, our observations were regarding effects of growth hormones, especially IBA, on shoot initiation are also supported by Ali [30] and Al-Amin et al. [5].

\section{Number of shoots bottle ${ }^{-1}$}

The statistical analysis of variance indicated that the trait of number of shoots produced per bottle was highly significant at 5\% probability level (Table 3, and Table 2). The mean results for different plant growth regulator concentrations showed highest number of shoots bottle ${ }^{-1}$ (16.25 shoots) under the MS media supplemented with 4.00 $\mathrm{mg} \mathrm{l}^{-1} \mathrm{IAA}+6.00 \mathrm{mg} \mathrm{l}^{-1} \mathrm{IBA}+4.00 \mathrm{mg} \mathrm{l}^{-1}$ NAA and $40 \mathrm{~g}$ sucrose $\mathrm{l}^{-1}$, followed by MS media containing $3.00 \mathrm{mg} \mathrm{l}^{-1} \mathrm{IAA}+4.00 \mathrm{mg}$ $\mathrm{l}^{-1} \mathrm{BAP}+3.00 \mathrm{mg}^{-1} \mathrm{NAA}$ and $40 \mathrm{~g} \mathrm{l}^{-1}$ sucrose (14.75 shoots); while minimum number of shoots bottle ${ }^{-1}$ (11.94) were obtained under MS media having $2.00 \mathrm{mg} \mathrm{l}^{-1}$ $\mathrm{IAA}+2.00 \mathrm{mg} \mathrm{l}^{-1} \mathrm{BAP}+2.00 \mathrm{mg} \mathrm{l}^{-1} \mathrm{NAA}$ and $40 \mathrm{~g} \mathrm{l}^{-1}$ sucrose. The mean results of gamma radiation doses indicated that maximum number of shoots bottle ${ }^{-1}(22.72$ shoots) were achieved at $20 \mathrm{~Gy}$, followed by 10 Gy (15.83 shoots), whereas lowest number of shoots bottle ${ }^{-1}$ (6.30 shoots) were obtained at $30 \mathrm{~Gy}$.

The combinatorial interaction of different plant growth regulator concentrations and gamma radiation doses depicted maximum number of shoots bottle ${ }^{-1}$ (25.77 and 23.88 shoots) under the MS media supplied with $4.00 \mathrm{mg} \mathrm{l}^{-1} \mathrm{IAA}+6.00 \mathrm{mg} \mathrm{l}^{-1} \mathrm{IBA}+4.00$ $\mathrm{mg} \mathrm{l}^{-1} \mathrm{NAA}+40 \mathrm{~g} \mathrm{l}^{-1}$ sucrose and $3.00 \mathrm{mg} \mathrm{l}^{-}$ ${ }^{1} \mathrm{IAA}+4.00 \mathrm{mg} \mathrm{l}^{-1} \mathrm{BAP}+3.00 \mathrm{mg} \mathrm{l}^{-1} \mathrm{NAA}$ $+40 \mathrm{~g} \mathrm{l}^{-1}$ sucrose at $20 \mathrm{~Gy}$; while minimum 
number of shoots bottle ${ }^{-1}$ (5.22 shoots) were observed under the concentration of $\mathrm{MS}+$ $2.00 \mathrm{mg} \mathrm{l}^{-1} \mathrm{IAA}+2.00 \mathrm{mg} \mathrm{l}^{-1} \mathrm{BAP}+2.00$ $\mathrm{mg} \mathrm{l}^{-1} \mathrm{NAA}+40 \mathrm{~g} \mathrm{l}^{-1}$ sucrose at $30 \mathrm{~Gy}$.

The results lied parallel with the report of Muhammad et al. [31] who reported the superior number of shoots under media supplied with $4.0 \mathrm{mg} \mathrm{l}^{-1} \mathrm{BAP}$ and $1.0 \mathrm{mg} \mathrm{L}^{-1}$ IAA. Habiba et al. [32] and Ahmed et al. [33] also observed high number of shoots under $4.0 \mathrm{mg} \mathrm{l}^{-1}$ BAP. Gübbük et al. [34] and Ngomuo et al. [20] mentioned that shoot development is also dictated by cytokinin concentration in the culture media, apart from the factor of genotype under consideration. Suitable cytokinin concentrations not only inhibit the apical dominancy [18], but their presence also controls the organogenesis [33].

Al-Amin et al. [5] mentioned results similar to our study presenting that concentrations of IBA and NAA played dictating role in shoot multiplication and proliferation. Likewise, Mukhambetzhanov et al. [35] suggested that the growth media treatments containing IBA worked best for shoot regeneration from nodal segments. Bhosale et al. [36] proposed higher average number of shoots in elevated concentrations of BAP in their study. Sinha et al. [37] also used different concentrations of BAP and found that higher shoot induction and proliferation was produced on basal MS media fortified with higher concentrations of BAP. They encountered optimal response for shoot bud induction and multiplication in the $\mathrm{MS}$ media containing $8.00 \mathrm{mg} \mathrm{l}^{-1} \mathrm{BAP}$; however, successive optimal shoot proliferation was seen in media supplemented with relatively lower concentration of BAP $\left(4.00 \mathrm{mg} \mathrm{l}^{-1}\right)$.

Regarding the variations observed for gamma radiation treatments, results of the study agreed to Mishra et al. [28] who proposed that the doses of 10 and 20 Gy impacted the shoot proliferation positively; moreover, Novak and Micke [38] also reported that the dose of 10 Gy stimulated explants growth and shoot formation. However, contrary to our observations, Ganapathi et al. [24] have presented that the viable shoots could be obtained from suckers irradiated up to $100 \mathrm{~Gy}$. Nevertheless, Ferid et al. [29] reported decline in shoot multiplication after 30 Gy dose of gamma radiation and observed the doses of 40 and $50 \mathrm{~Gy}$ to be completely lethal for all varieties in the study. Agreeing to our observations, stimulatory effects of lesser doses of gamma radiation on shoot multiplication have also been reported earlier [39, 40].

\section{Shoot length}

The statistical analysis of variance indicated that the interaction of independent variables of the study and the shoots length was highly significant at $5 \%$ probability level (Table 4). The results of different plant growth regulator concentrations indicated that maximum shoot length bottle ${ }^{-1}(10.72$ $\mathrm{cm})$ was recorded under the media concentration of $\mathrm{MS}+4.00 \mathrm{mg} \mathrm{l}^{-1} \mathrm{IAA}+$ $6.00 \mathrm{mg} \mathrm{l}^{-1} \mathrm{IBA}+4.00 \mathrm{mg} \mathrm{l}^{-1} \mathrm{NAA}+40 \mathrm{~g} \mathrm{l}^{-1}$ sucrose, followed by $9.22 \mathrm{~cm}$ long shoots on MS media containing $3.00 \mathrm{mg} \mathrm{l}^{-1} \mathrm{IAA}+4.00$ $\mathrm{mg} \mathrm{l}^{-1} \mathrm{BAP}+3.00 \mathrm{mg} \mathrm{l}^{-1} \mathrm{NAA}+40 \mathrm{~g} \mathrm{l}^{-1}$ sucrose. The minimum shoot length bottle ${ }^{-1}$ was observed under the MS media composition having $2.00 \mathrm{mg} \mathrm{l}^{-1} \mathrm{IAA}+2.00$ $\mathrm{mg} \mathrm{l}^{-1} \mathrm{BAP}+2.00 \mathrm{mg} \mathrm{l}^{-1} \mathrm{NAA}+40 \mathrm{~g} \mathrm{l}^{-1}$ sucrose $(7.66 \mathrm{~cm})$. The mean results of gamma radiation doses showed the longest shoots of the plantlets at 20 and $10 \mathrm{~Gy}$, (14.63 and $11.38 \mathrm{~cm}$, respectively), while minimum shoot length bottle ${ }^{-1}$ was observed under $30 \mathrm{~Gy}(3.72 \mathrm{~cm})$.

The interaction of different plant growth regulator concentrations and gamma radiation doses showed maximum shoot length bottle ${ }^{-1}$ under the MS media supplemented with $4.00 \mathrm{mg} \mathrm{l}^{-1} \mathrm{IAA}+6.00$ $\mathrm{mg} \mathrm{l}^{-1} \mathrm{IBA}+4.00 \mathrm{mg} \mathrm{l}^{-1} \mathrm{NAA}+40 \mathrm{~g} \mathrm{l}^{-1}$ sucrose, and $3.00 \mathrm{mg} \mathrm{l}^{-1} \mathrm{IAA}+4.00 \mathrm{mg} \mathrm{l}^{-1}$ 
$\mathrm{BAP}+3.00 \mathrm{mg} \mathrm{l}^{-1} \mathrm{NAA}+40 \mathrm{~g} \mathrm{l}^{-1}$ sucrose at 20 Gy (17.44 and $15.00 \mathrm{~cm}$, respectively), whereas minimum shoot length bottle ${ }^{-1}$ was recorded under the concentration of $\mathrm{MS}+$ $5.00 \mathrm{mg} \mathrm{l}^{-1} \mathrm{IAA}+8.00 \mathrm{mg} \mathrm{l}^{-1} \mathrm{IBA}+5.00 \mathrm{mg}$ $\mathrm{l}^{-1} \mathrm{NAA}+40 \mathrm{~g} \mathrm{l}^{-1}$ sucrose at $30 \mathrm{~Gy}(3.22$ $\mathrm{cm})$.

Al-Amin et al. [5] also observed the good shoot elongation in media supplemented with high quantities of BAP. Moreover, role of IBA in shoot elongation has also been reported. Radiation of the in vitro multiple shoots adversely effected elongation, except for doses 10 to 20Gy, which were observed to significantly enhance shoot elongation. Parallel to the results of this study, Karmarkar et al. [39] also found lower doses of gamma radiation such as 10 to $15 \mathrm{~Gy}$ to produce optimum shoot length in the plantlets, using a range of doses from 10 to 100 Gy. A stimulatory effect of lower doses of radiation on in vitro shoot elongation have been observed by Siddiqui et al. [10] as well.

\section{Number of leaves}

The results of different plant growth regulator concentrations showed that maximum number of leaves were recorded in the media concentration of $\mathrm{MS}+3.00 \mathrm{mg}$ $\mathrm{l}^{-1} \mathrm{IAA}+4.00 \mathrm{mg} \mathrm{l}^{-1} \mathrm{BAP}+3.00 \mathrm{mg} \mathrm{l}^{-1}$ NAA + $40 \mathrm{~g} \mathrm{l}^{-1}$ sucrose (10.00 leaves), followed by the MS media having $4.00 \mathrm{mg} \mathrm{l}^{-}$ ${ }^{1} \mathrm{IAA}+6.00 \mathrm{mg} \mathrm{l}^{-1} \mathrm{IBA}+4.00 \mathrm{mg} \mathrm{l}^{-1} \mathrm{NAA}$ $+40 \mathrm{~g} \mathrm{l}^{-1}$ sucrose (Table 5). The minimum number of leaves were seen in MS media supplied with $2.00 \mathrm{mg} \mathrm{l}^{-1} \mathrm{IAA}+2.00 \mathrm{mg} \mathrm{l}^{-1}$ $\mathrm{BAP}+2.00 \mathrm{mg} \mathrm{l}^{-1} \mathrm{NAA}+40 \mathrm{~g} \mathrm{l}^{-1}$ sucrose (7.00 leaves).

Mean results of different gamma radiation doses indicated that maximum number of leaves were produced at 20Gy (10.75 leaves), followed by 10 Gy (8.88 leaves), whereas minimum number of leaves were obtained under control (6.27 leaves). The interaction of different plant growth regulator concentrations and gamma radiation doses indicated that higher number of leaves bottle ${ }^{-1}$ were recorded under the media concentration of $\mathrm{MS}+3.00 \mathrm{mg} \mathrm{l}^{-1}$ $\mathrm{IAA}+4.00 \mathrm{mg} \mathrm{l}^{-1} \mathrm{BAP}+3.00 \mathrm{mg} \mathrm{l}^{-1} \mathrm{NAA}+$ $40 \mathrm{~g} \mathrm{l}^{-1}$ sucrose at $20 \mathrm{~Gy}$ (13.89 leaves) and minimum number of leaves bottle ${ }^{-1}$ were achieved under MS media supplemented with $2.00 \mathrm{mg} \mathrm{l}^{-1} \mathrm{IAA}+2.00 \mathrm{mg} \mathrm{l}^{-1} \mathrm{BAP}+$ $2.00 \mathrm{mg} \mathrm{l}^{-1} \mathrm{NAA}+40 \mathrm{~g} \mathrm{l}^{-1}$ sucrose in control (5.11 leaves).

Rahman et al. [41] reported that combination of BAP and NAA produced excellent number of leaves in plantlets which was in line with our observations. Ali et al. [42] also studied the effects of growth regulators for leaves development and shoot formation in MS media and suggested a paramount role of NAA and BAP. Moreover, Al-Amin [5] also mentioned similar role of growth promoters. Further, regarding gamma radiation treatment, Khatri et al. [27] used the efficient culture medium for in vitro propagation of banana cultivars and reported stimulatory role of lower doses of gamma radiation.

It was evident from the results of the study that lower doses of gamma radiation i.e. 10 and 20 Gy played stimulatory role for shoot initiation, and elongation as well as leaves development. While, growth regulators like BAP and NAA were seen to play important role in plantlets' development and growth for banana. The experiment also reported optimal concentrations of growth media for tissue culture of banana variety basrai, which can find applications for rapid multiplication of the said variety on large scale. The plantlets developed in this study are anticipated to be genetically different because of radiation treatments; hence, the elite plants can find applications towards varietal development program for banana in the country. 
Table 1. Effect of different concentrations of growth regulators and doses of gamma radiation on days taken to shoot initiation by banana variety Basrai

\begin{tabular}{|c|c|c|c|c|c|}
\hline \multirow{2}{*}{ Concentrations } & \multicolumn{4}{|c|}{ Doses of Gamma Radiation (Gy) } & \multirow{2}{*}{ Mean } \\
\hline & $\mathbf{0}$ & 10 & 20 & 30 & \\
\hline $\begin{array}{c}\mathrm{MS}+2.00 \mathrm{mg} \mathrm{l}^{-1} \mathrm{IAA}+2.00 \mathrm{mg} \mathrm{l}^{-1} \mathrm{BAP}+2.00 \mathrm{mg} \mathrm{l}^{-1} \mathrm{NAA}+ \\
40 \mathrm{~g} \mathrm{l}^{-1} \text { sucrose }\end{array}$ & $31.22 \mathrm{~cd}$ & $30.44 \mathrm{~d}$ & $26.55 \mathrm{fg}$ & $35.77 \mathrm{a}$ & $31.00 \mathrm{a}$ \\
\hline $\begin{array}{c}\mathrm{MS}+3.00 \mathrm{mg} \mathrm{l}^{-1} \mathrm{IAA}+4.00 \mathrm{mg} \mathrm{l}^{-1} \mathrm{BAP}+3.00 \mathrm{mg} \mathrm{l}^{-1} \mathrm{NAA}+ \\
40 \mathrm{~g} \mathrm{l}^{-1} \text { sucrose }\end{array}$ & $29.00 \mathrm{e}$ & $27.33 \mathrm{f}$ & $24.22 \mathrm{~h}$ & $31.00 \mathrm{~cd}$ & $27.88 \mathrm{c}$ \\
\hline $\begin{array}{c}\mathrm{MS}+4.00 \mathrm{mg} \mathrm{l}^{-1} \mathrm{IAA}+6.00 \mathrm{mg} \mathrm{l}^{-1} \mathrm{IBA}+4.00 \mathrm{mg} \mathrm{l}^{-1} \mathrm{NAA}+ \\
40 \mathrm{~g} \mathrm{l}^{-1} \text { sucrose }\end{array}$ & $26.67 \mathrm{fg}$ & $24.55 \mathrm{~h}$ & $21.55 \mathrm{i}$ & $31.55 \mathrm{c}$ & $26.08 \mathrm{~d}$ \\
\hline $\begin{array}{c}\mathrm{MS}+5.00 \mathrm{mg} \mathrm{l}^{-1} \mathrm{IAA}+8.00 \mathrm{mg} \mathrm{l}^{-1} \mathrm{IBA}+5.00 \mathrm{mg} \mathrm{l}^{-1} \mathrm{NAA}+ \\
40 \mathrm{~g} \mathrm{l}^{-1} \text { sucrose }\end{array}$ & $29.11 \mathrm{e}$ & $29.22 \mathrm{e}$ & $25.89 \mathrm{~g}$ & $34.33 \mathrm{~b}$ & $29.63 \mathrm{~b}$ \\
\hline Mean & $29.00 \mathrm{~b}$ & $27.88 \mathrm{c}$ & $24.55 \mathrm{~d}$ & $33.16 \mathrm{a}$ & \\
\hline
\end{tabular}

Concentrations SE (0.2556), LSD (5\%) (0.5220); Doses of gamma radiation SE (0.2556), LSD (5\%) (0.5220); Concentrations x Doses of gamma radiation SE (0.5122), LSD (5\%) (1.0440).

Table 2. Mean square for days taken to shoot initiation bottle ${ }^{-1}$, number of shoots bottle ${ }^{-1}$, shoot length bottle ${ }^{-1}$ and number of leaves bottle $^{-1}$ under different concentrations of plant growth regulators and doses of gamma radiation

\begin{tabular}{|c|c|c|c|c|c|}
\hline Source & DF & $\begin{array}{l}\text { Days taken to shoot } \\
\text { initiation bottle }{ }^{-1}\end{array}$ & $\begin{array}{c}\text { Number of shoots } \\
\text { bottle }^{-1}\end{array}$ & $\begin{array}{c}\text { Shoot length }(\mathrm{cm}) \\
\text { bottle }^{-1}\end{array}$ & $\begin{array}{c}\text { Number of leaves } \\
\text { bottle }^{-1}\end{array}$ \\
\hline Replications & 2 & 2.641 & 4.687 & 1.301 & 0.1212 \\
\hline Concentrations $(\mathrm{C})$ & 3 & $54.655^{* *}$ & $40.783^{* *}$ & $21.417 * *$ & $21.8112 * *$ \\
\hline Doses of gamma radiation (DGR) & 3 & $151.433 * *$ & $579.945 * *$ & $294.846 * *$ & $54.4515 * *$ \\
\hline $\mathrm{C} \times \mathrm{DGR}$ & 9 & $1.939 * *$ & $2.077 * *$ & $1.270 * *$ & $1.2758 * *$ \\
\hline Error & 30 & 0.392 & 0.141 & 0.166 & 0.1888 \\
\hline
\end{tabular}


Table 3. Effect of different concentrations of growth regulators and doses of gamma radiation on number of shoots of banana variety Basrai

\begin{tabular}{|c|c|c|c|c|c|}
\hline \multirow{2}{*}{ Concentrations } & \multicolumn{4}{|c|}{ Doses of Gamma Radiation (Gy) } & \multirow{2}{*}{ Mean } \\
\hline & $\mathbf{0}$ & 10 & 20 & 30 & \\
\hline $\begin{array}{c}\mathrm{MS}+2.00 \mathrm{mg} \mathrm{l}^{-1} \mathrm{IAA}+2.00 \mathrm{mg} \mathrm{l}^{-1} \mathrm{BAP}+2.00 \mathrm{mg} \mathrm{l}^{-1} \mathrm{NAA}+40 \\
\mathrm{~g} \mathrm{l}^{-1} \text { sucrose }\end{array}$ & $9.33 \mathrm{k}$ & $13.55 \mathrm{~h}$ & $19.67 \mathrm{~d}$ & $5.22 \mathrm{n}$ & $11.94 \mathrm{~d}$ \\
\hline $\begin{array}{c}\mathrm{MS}+3.00 \mathrm{mg} \mathrm{l}^{-1} \mathrm{IAA}+4.00 \mathrm{mg} \mathrm{l}^{-1} \mathrm{BAP}+3.00 \mathrm{mg} \mathrm{l}^{-1} \mathrm{NAA}+40 \\
\mathrm{~g} \mathrm{l}^{-1} \text { sucrose }\end{array}$ & $12.33 \mathrm{i}$ & $16.22 \mathrm{f}$ & $23.88 \mathrm{~b}$ & $6.55 \mathrm{~lm}$ & $14.75 \mathrm{~b}$ \\
\hline $\begin{array}{c}\mathrm{MS}+4.00 \mathrm{mg} \mathrm{l}^{-1} \mathrm{IAA}+6.00 \mathrm{mg} \mathrm{l}^{-1} \mathrm{IBA}+4.00 \mathrm{mg} \mathrm{l}^{-1} \mathrm{NAA}+40 \mathrm{~g} \\
\mathrm{l}^{-1} \text { sucrose }\end{array}$ & $13.55 \mathrm{~h}$ & $18.55 \mathrm{e}$ & $25.77 \mathrm{a}$ & 7.111 & $16.25 \mathrm{a}$ \\
\hline $\begin{array}{c}\mathrm{MS}+5.00 \mathrm{mg} \mathrm{l}^{-1} \mathrm{IAA}+8.00 \mathrm{mg} \mathrm{l}^{-1} \mathrm{IBA}+5.00 \mathrm{mg} \mathrm{l}^{-1} \mathrm{NAA}+40 \mathrm{~g} \\
\mathrm{l}^{-1} \text { sucrose }\end{array}$ & $10.67 \mathrm{j}$ & $15.00 \mathrm{~g}$ & $21.55 \mathrm{c}$ & $6.33 \mathrm{~m}$ & $13.39 \mathrm{c}$ \\
\hline Mean & $11.47 \mathrm{c}$ & $15.83 \mathrm{~b}$ & $22.72 \mathrm{a}$ & $6.30 \mathrm{~d}$ & \\
\hline
\end{tabular}

Concentrations SE (0.1534), LSD (5\%) (0.3134); Doses of gamma radiation SE (0.1534), LSD (5\%) (0.3134); Concentrations x Doses of gamma radiation SE (0.3069), LSD (5\%) (0.6268).

Table 4. Effect of different concentrations of growth regulators and doses of gamma radiation on shoots length (cm) of banana variety Basrai

\begin{tabular}{|c|c|c|c|c|c|}
\hline \multirow{2}{*}{ Concentrations } & \multicolumn{4}{|c|}{ Doses of Gamma Radiation (Gy) } & \multirow{2}{*}{ Mean } \\
\hline & $\mathbf{0}$ & 10 & 20 & 30 & \\
\hline $\begin{array}{c}\mathrm{MS}+2.00 \mathrm{mg} \mathrm{l}^{-1} \mathrm{IAA}+2.00 \mathrm{mg} \mathrm{l}^{-1} \mathrm{BAP}+2.00 \mathrm{mg} \mathrm{l}^{-1} \mathrm{NAA}+ \\
40 \mathrm{~g} \mathrm{l}^{-1} \text { sucrose }\end{array}$ & $4.88 \mathrm{i}$ & $9.88 \mathrm{f}$ & $12.55 \mathrm{de}$ & $3.33 \mathrm{j}$ & $7.66 \mathrm{~d}$ \\
\hline $\begin{array}{c}\mathrm{MS}+3.00 \mathrm{mg} \mathrm{l}^{-1} \mathrm{IAA}+4.00 \mathrm{mg} \mathrm{l}^{-1} \mathrm{BAP}+3.00 \mathrm{mg} \mathrm{l}^{-1} \mathrm{NAA}+ \\
40 \mathrm{~g} \mathrm{l}^{-1} \text { sucrose }\end{array}$ & $6.22 \mathrm{~h}$ & $12.00 \mathrm{e}$ & $15.00 \mathrm{~b}$ & $3.66 \mathrm{j}$ & $9.22 \mathrm{~b}$ \\
\hline $\begin{array}{c}\mathrm{MS}+4.00 \mathrm{mg} \mathrm{l}^{-1} \mathrm{IAA}+6.00 \mathrm{mg} \mathrm{l}^{-1} \mathrm{IBA}+4.00 \mathrm{mg} \mathrm{l}^{-1} \mathrm{NAA}+ \\
40 \mathrm{~g} \mathrm{l}^{-1} \text { sucrose }\end{array}$ & $7.66 \mathrm{~g}$ & $13.11 \mathrm{~cd}$ & $17.44 \mathrm{a}$ & $4.67 \mathrm{i}$ & $10.72 \mathrm{a}$ \\
\hline $\begin{array}{c}\mathrm{MS}+5.00 \mathrm{mg} \mathrm{l}^{-1} \mathrm{IAA}+ \\
40.00 \mathrm{mg} \mathrm{l}^{-1} \mathrm{IBA}+5.00 \mathrm{mg} \mathrm{l}^{-1} \mathrm{NAA}+ \\
40 \text { sucrose }\end{array}$ & $5.66 \mathrm{~h}$ & $10.55 \mathrm{f}$ & $13.55 \mathrm{c}$ & $3.22 \mathrm{j}$ & $8.25 \mathrm{c}$ \\
\hline Mean & $6.11 \mathrm{c}$ & $11.38 \mathrm{~b}$ & $14.63 \mathrm{a}$ & $3.72 \mathrm{~d}$ & \\
\hline
\end{tabular}

Concentrations SE (0.1663), LSD (5\%) (0.3396); Doses of gamma radiation SE (0.1663), LSD (5\%) (0.3396); Concentrations x Doses of gamma radiation SE (0.3326), LSD (5\%) (0.6792). 
Pure Appl. Biol., 9(1): 1230-1241, March, 2020 http://dx.doi.org/10.19045/bspab.2020.90003

Table 5. Effect of different concentrations of growth regulators and doses of gamma radiation on number of leaves of banana variety Basrai

\begin{tabular}{|c|c|c|c|c|c|}
\hline \multirow{2}{*}{ Concentrations } & \multicolumn{4}{|c|}{ Doses of Gamma Radiation (Gy) } & \multirow{2}{*}{ Mean } \\
\hline & $\mathbf{0}$ & 10 & 20 & 30 & \\
\hline $\begin{array}{c}\mathrm{MS}+2.00 \mathrm{mg} \mathrm{l}^{-1} \mathrm{IAA}+2.00 \mathrm{mg} \mathrm{l}^{-1} \mathrm{BAP}+2.00 \mathrm{mg} \mathrm{l}^{-1} \mathrm{NAA}+ \\
40 \mathrm{~g} \mathrm{l}^{-1} \text { sucrose }\end{array}$ & $5.11 \mathrm{~h}$ & $7.66 \mathrm{~d}$ & $9.55 \mathrm{c}$ & $5.66 \mathrm{gh}$ & $7.00 \mathrm{c}$ \\
\hline $\begin{array}{c}\mathrm{MS}+3.00 \mathrm{mg} \mathrm{l}^{-1} \mathrm{IAA}+4.00 \mathrm{mg} \mathrm{l}^{-1} \mathrm{BAP}+3.00 \mathrm{mg} \mathrm{l}^{-1} \mathrm{NAA}+ \\
40 \mathrm{~g} \mathrm{l}^{-1} \text { sucrose }\end{array}$ & $7.78 \mathrm{~d}$ & $10.88 \mathrm{~b}$ & $13.89 \mathrm{a}$ & $7.44 \mathrm{~d}$ & $10.00 \mathrm{a}$ \\
\hline $\begin{array}{c}\mathrm{MS}+4.00 \mathrm{mg} \mathrm{l}^{-1} \mathrm{IAA}+6.00 \mathrm{mg} \mathrm{l}^{-1} \mathrm{IBA}+4.00 \mathrm{mg} \mathrm{l}^{-1} \mathrm{NAA}+ \\
40 \mathrm{~g} \mathrm{l}^{-1} \text { sucrose }\end{array}$ & 6.44 ef & $9.00 \mathrm{c}$ & $10.33 \mathrm{~b}$ & $6.55 \mathrm{e}$ & $8.08 \mathrm{~b}$ \\
\hline $\begin{array}{c}\mathrm{MS}+5.00 \mathrm{mg} \mathrm{l}^{-1} \mathrm{IAA}+8.00 \mathrm{mg} \mathrm{l}^{-1} \mathrm{IBA}+5.00 \mathrm{mg} \mathrm{l}^{-1} \mathrm{NAA}+ \\
40 \mathrm{~g} \mathrm{l}^{-1} \text { sucrose }\end{array}$ & $5.78 \mathrm{f}-\mathrm{h}$ & $8.00 \mathrm{~d}$ & $9.22 \mathrm{c}$ & $6.22 \mathrm{e}-\mathrm{g}$ & $7.30 \mathrm{c}$ \\
\hline Mean & $6.27 \mathrm{c}$ & $8.88 \mathrm{~b}$ & $10.75 \mathrm{a}$ & $6.47 \mathrm{c}$ & \\
\hline
\end{tabular}

Concentrations SE (0.1774), LSD (5\%) (0.3622); Doses of gamma radiation SE (0.1774), LSD (5\%) (0.3622); Concentrations x Doses of gamma radiation SE (0.3547), LSD (5\%) (0.7245) 


\section{Conclusion}

The study presented a stimulatory role of two of the lower doses of gamma radiation viz. 10 and 20 Gy towards shoot initiation and elongation as well as leaves development in banana. Moreover, growth regulators like IBA, BAP and NAA were seen to play important role in plantlets' differentiation, development and growth.

\section{Authors' contributions}

Conceived and designed the experiments: IA Khan \& GS Nizamani, Performed the experiments: A Siddiqui \& S Yasmeen, Analyzed the data: MA Siddiqui \& MR Nizamani, Contributed reagents/ materials/ analysis tools: F Nizamani \& MA Khaskheli, Wrote the paper: MT Khan, M Ali \& SK Baloch.

\section{References}

1. Ghosh A, Ganapathi TR, Nath P, \& Bapat VA (2009). Establishment of embryogenic cell suspension cultures and Agrobacterium-mediated transformation in an important Cavendish banana cv. Robusta (AAA). Plant Cell Tissue Organ Cult 97: 131139.

2. Shapira OR, Khadka S, Israeli Y, Shani URI, \& Schwartz A (2009). Functional anatomy controls ion distribution in banana leaves: significance of $\mathrm{Na}^{+}$seclusion at the leaf margins. Plant Cell Environ 32: 476-485.

3. Darvari FM, Sariah M, Puad MP, \& Maziah M (2010). Micropropagation of some Malaysian banana and plantain (Musa sp.) cultivars using male flowers. Afr J Biotechnol 9: 2360-2366.

4. Rahman S, Biswas N, Hassan MM, Ahmed MG, Mamun ANK, Islam MR, Moniruzzaman $\mathrm{M}$, \& Haque ME (2013). Micropropagation of banana (Musa sp.) cv. Agnishwar by in vitro shoot tip culture. Intl Res J Biotechnol 4: 83-88.

5. Al-Amin M, Karim MR, Amin MR, Rahman S, \& Mamun ANM (2009). in vitro micro propagation of banana
(Musa spp.). Banglad J Agric Res 34: 645-659.

6. Agriculture Marketing Information Service (2017). Province wise production of banana. http://www.amis.pk/Agristatistics/Data /HTML Final/Banana/Production.html. Accessed 16 Apr 2019.

7. Agriculture Marketing Information Service (2017). Province wise area of banana.

http://www.amis.pk/Agristatistics/Data /HTML Final/Banana/area.html. Accessed 16 Apr 2019.

8. FAOSTAT (2017). Banana production in the world. http://www.fao.org/faostat/en/\#data/Q C/visualize. Accessed 17 Apr 2019.

9. Bidabadi SS, Meon S, Wahab Z, Subramaniam S, \& Mahmood M (2012). Induced mutations for enhancing variability of banana (Musa spp.) shoot tip cultures using ethyl methanesulphonate (EMS). Aust $J$ Crop Sci 6: 391.

10. Siddiqui SH, Khatri A, Khan IA, Nizamani G, \& Khan R (1995). Improvement of banana (Musa cvs.) through in vitro culture techniques and induced mutations, IAEA Report: No. IAEA-TECDOC 800.

11. Gaspar TH, Kevers C, Faivre-Rampant $\mathrm{O}$, Crèvecoeur M, Penel CL, Greppin H, \& Dommes J (2003). Changing concepts in plant hormone action. Intl Vitr Cell Dev Biol 39: 85.

12. Yadav S, Ahmad A, \& Lal M (2012). Effect of different auxins and cytokinins on in vitro multiplication and rooting of shoot cultures in Sugarcane. Intl J Biol Pharma Res 3: 814-818.

13. Soomro NS, Khan IA, Baloch S, Ghulam Shah Nizamani Shafquat Yasmeen, \& Khan MT (2016). Effect of phytohormones on shoot and root regeneration in rose under in vitro conditions. Pak J Biotechnol 13: 199203. 
14. Khan MT, Seema N, Khan IA, \& Yasmine S (2017). Characterization of somaclonal variants of sugarcane on the basis of quantitative, qualitative, and genetic attributes. Pak J Bot 49: 2429-2443.

15. Khan MT, Seema N, Khan IA, \& Yasmine S (2017). Characterization of somaclonal variants of sugarcane on the basis of quantitative, qualitative, and genetic attributes. Pak J Bot 49: 2429-2443.

16. North JJ, Ndakidemi PA, \& Laubscher CP (2012). Effects of antioxidants, plant growth regulators and wounding on phenolic compound excretion during micropropagation of Strelitzia reginae. Intl J Phys Sci 7: 638-646.

17. Ngomuo M, Mneney E, \& Ndakidemi PA (2014). The in vitro propagation techniques for producing banana using shoot tip cultures. Am J Plant Sci $5(11)$.

18. Jafari N, Othman RY, \& Khalid N (2011). Effect of benzylaminopurine (BAP) pulsing on in vitro shoot multiplication of Musa acuminata (banana) cv. Berangan. Afr $J$ Biotechnol 10: 2446-2450.

19. Sipen P, \& Davey MR (2012). Effects of N6-benzylaminopurine and indole acetic acid on in vitro shoot multiplication, nodule-like meristem proliferation and plant regeneration of Malaysian bananas (Musa spp.). Trop life Sci Res 23: 67.

20. Ngomuo M, Mneney E, \& Ndakidemi $P$ (2013). The effects of auxins and cytokinin on growth and development of (Musa sp.) var. "Yangambi" explants in tissue culture. Am J Plant Sci 4: 2174-2180.

21. Madhulatha $P$, Anbalagan $M$, Jayachandran S, \& Sakthivel N (2004). Influence of liquid pulse treatment with growth regulators on in vitro propagation of banana (Musa spp. AAA). Plant Cell Tissue Organ Cult 76: 189-192.
22. Strosse H, Schoofs H, Panis B, Andre E, Reyniers K, \& Swennen R (2006). Development of embryogenic cell suspensions from shoot meristematic tissue in bananas and plantains (Musa spp.). Plant Sci 170: 104-112.

23. Novak FJ, Afza R, Duren M van, \& Omar MS (1990). Mutation induction by gamma irradiation of in vitro cultured shoot-tips of banana and plantain (Musa cvs). Trop Agric 67: 21-28.

24. Ganapathi TR, Suprasanna P, Bapat VA, \& Rao PS (1992). Propagation of banana through encapsulated shoot tips. Plant Cell Rep 11: 571-575.

25. Gomez KA, Gomez KA, \& Gomez AA (1984). Statistical procedures for agricultural research. John Wiley \& Sons.

26. Kulkarni VM, Suprasanna P, Ganapathi TR, Bapat VA, \& Rao PS (2004). Differential effects of genome and cytokinins on shoot-tip cultures of Indian banana cultivars (Musa spp.). Physiol Mol Biol Plants 10: 75-81.

27. Khatri A, Bibi S, Dahot MU, Khan IA, \& Nizamani GS (2011). in vitro mutagenesis in banana and variant screening through ISSR. Pak J Bot 43: 2427-2431.

28. Mishra PJ, Ganapathi TR, Suprasanna P, \& Bapat VA (2007). Effect of single and recurrent gamma irradiation on in vitro shoot cultures of banana. Intl $J$ Fruit Sci 7: 47-57.

29. Ferid A, Fatimah K, \& Suhana Z (2018). Gamma irradiation effect on the growth of Musa cv. Tanduk (AAB). Asian J Agric Biol 6: 135-142.

30. Ali H (1996) Effect of BAP and IBA on micropropagation of some banana cultivars. M.S. thesis. Deptt. of Hortic., Banglad. Agric. Univ. Mymensingh.

31. Muhammad A, Rashid H, Hussain I, \& Naqvi SMS (2007). Proliferation-rate effects of BAP and kinetin on banana (Musa spp. AAA Group) 'Basrai.' Hort Sci 42: 1253-1255. 
32. Habiba U, Reza S, Saha ML, Khan MR, \& Hadiuzzaman S (2002). Endogenous bacterial contamination during in vitro culture of table banana: Identification and prevention. Plant Tissue Cult 12: 117-124.

33. Ahmed S, Sharma A, Bhushan B, Singh AK, \& Wali VK (2014). Effect of carbohydrate source, $\mathrm{pH}$ and supporting media on in vitro rooting of banana (Musa spp.) cv. Grand naine plantlets. Afr J Agric Res 9: 11351140.

34. Gübbük H, \& Pekmezci M (2004). In vitro propagation of some new banana types (Musa spp.). Turkish J Agric 28: 355-361.

35. Mukhambetzhanov SK, Nam $\mathrm{S} V$, Vecherko NA, \& Mursalieva VK (2010). Factors affecting the growth and development of roses in vitro. Biotechnol Theory Pract 1: 41-52.

36. Bhosale UP, Dubhashi S V, \& Mali NS (2013). in vitro rooting of different species of banana. Adv Appl Sci Res 4: 115-118.

37. Sinha RK, Saha PR, Das AB, Jena SN, \& Sinha S (2018). In vitro Clonal Propagation of Musa sp. Cultivar Gopi: A Palatable Banana of Tripura, India. Am J Plant Biol 3: 12.
38. Novak FJ, \& Micke A (1988). Mutation breeding and in vitro techniques for crop improvement in developing countries. In gene manipulation for plant improvement in developing countries. Proc. Kualalumpur SABRAO, pp 63-86.

39. Karmarkar VM, Kulkarni VM, Suprasanna P, Bapat VA, \& Rao PS (2001). Radio-sensitivity of in vivo and in vitro cultures of banana cv. Basrai (AAA). Fruits 56: 67-74.

40. Qamar M, Qureshi ST, Khan IA, Memon SA, Bano Z, \& Solangi SK (2016). Influence of gamma radiation on the physiochemical properties of in vitro triploid and tetraploid banana species. Pak J Biotechnol 13: 237-244.

41. Rahman MZ, Nasiruddin KM, Amin MA, \& Islam MN (2004). in vitro response and shoot multiplication of banana with BAP and NAA. Asian $J$ Plant Sci 3: 406-409.

42. Ali A, Sajid A, Naveed NH, Majid A, Saleem A, Khan UA, Jafery FI, \& Naz $S$ (2011). Initiation, proliferation and development of micro-propagation system for mass scale production of banana through meristem culture. Afr J Biotechnol 10: 15731-15738. 